\title{
WANT A BETTER CRIMINAL JUSTICE RESPONSE TO RAPE? IMPROVE POLICE INTERVIEWS WITH COMPLAINANTS AND SUSPECTS
}

\author{
Nina J. Westera* \\ ARC Centre of Excellence in Policing and Security, Griffith University, Queensland \\ * CORRESPONDING AUTHOR: C/O Griffith University; Mt Gravatt Campus, Brisbane, \\ Queensland, 4122, Australia \\ n.westera@griffith.edu.au; ph: 006173735 1017; fax: 0061737351033
}

Mark R. Kebbell

ARC Centre of Excellence in Policing and Security, Griffith University, Queensland m.kebbell@griffith.edu.au

\begin{abstract}
Becky Milne
Centre of Forensic Interviewing, Institute of Criminal Justice Studies, University of Portsmouth becky.milne@port.ac.uk; ph: 00447801055361
\end{abstract}

\section{FUNDING}

This research was conducted at the ARC Centre of Excellence in Policing and Security with funding from the Australian Research Council (SR07000002).

KEY WORDS: RAPE; INVESTIGATIVE INTERVIEWING; CRIMINAL INVESTIGATION. 


\begin{abstract}
Achieving just outcomes in rape cases is difficult, but there are ways we can improve the investigation and prosecution of these crimes, now. We outline how targeting variables, within control of the criminal justice system, can improve the quality of information police obtain from interviews with complainants and suspects. We explore how, by preserving these accounts on video, the criminal justice process can better use this information to improve effective decision making from investigation through to criminal trial through to prevention.
\end{abstract}


Achieving justice in cases of alleged sex offending against adults has long been acknowledged as a major criminal justice challenge (Estrich, 1987; Lees, 2002; Temkin \& Krahé, 2008). In a review of 75 attrition studies in the United States, Canada, England and Wales, Scotland, and Australia, it was found that between 1990 and 2005 on average only $12.5 \%$ of all sexual assault cases reported to police resulted in a conviction for any sexual offence (Daly \& Bouhours, 2010). There are many reasons for this, for example victims are often reluctant to come forward and report crime in the first place, and to give evidence in court (Stern, 2010). The fact that the most common defense of a rapist is that the sex was consensual means that advances in physical 'identification' evidence, such as DNA, adds little to determinations of criminal culpability (Johnson, Peterson, Sommers, \& Baskin, 2012). Instead, the accounts given by the complainant and alleged offender are often the central, and only, evidence in the case (Edwards, 2003; Lees, 2002). Having only one person's word against another makes it difficult to establish certainty about whether the crime of rape was committed ${ }^{1}$. Further, research suggests that when the evidence is ambiguous, decision makers such as investigators, prosecutors and jurors tend to defer to their stereotypes about rape that often attribute blame to the complainant (Estrich, 1987; Horney \& Spohn, 1996; Temkin \& Krahé, 2008).

Given this context it is easy to despair of ways of improving the investigation and prosecution of rape. However, by bringing together an extensive empirical literature, and a less extensive number of reviews and reports, it is clear there is much that can be done to enhance the investigation and prosecution of adult sex offences, immediately. This paper outlines the ways we believe can improve outcomes in rape investigations and prosecutions through the better utilization of police interviewing methods. Our approach is to target this 'system variable'. System variables are those within control of the justice system and were originally proposed in 
the context of eyewitness identifications (Wells, 1978). For example, the fairness of a photo spread shown to eyewitnesses is under the control of the system. In contrast, 'estimator variables' such as the stress a witness experienced or how quickly the event unfolded, are beyond the control of the system. In this paper we outline system variables that can be used to improve the likelihood that offenders who are guilty are convicted and those who are innocent are exonerated. First we examine how police can improve the quality of information gathered in interviews with the two main sources of information in these cases - the complainant and the alleged offender. Then we explore how, when preserved on video, this higher quality information can be better utilized to improve effective decision making at each stage of the criminal justice process from investigation through to a criminal trial. Finally we explore how police can use the information gleaned in these interviews to help prevent similar offending. We start with how police can gather the best quality information from the complainant. We argue that by applying cutting-edge research, technology, and thinking about the process as a whole, we can increase the likelihood of achieving justice.

\section{THE COMPLAINANT INTERVIEW}

First and foremost in any rape investigation, is the need to obtain an accurate and detailed account from the complainant. The hidden nature of offending means this account may be the only source of information for the investigation. No more so, when the alleged offence occurs in a country where the suspect can exercise the right to silence ${ }^{2}$. Memory research shows that how an account is elicited from an eyewitness is a system variable that can have a major influence on the accuracy and detail of information obtained (Geiselman et al., 1984; Lipton, 1977; Loftus \& Palmer, 1974). As a special type of witness, applying these research findings to how information is elicited from an adult rape complainant can dramatically improve the quality of her account. 
Accurate detail is especially important in rape cases because of the increased reporting of offences where the complainant and alleged offender are known to each other (Daly \& Bouhours, 2010; Planty, Langton, Krebs, Berzofsky, \& Smiley-McDonald, 2013). This means the issue of whether the complainant consented, or if the alleged offender had reasonable grounds to believe she consented, is likely to be central to establishing what occurred. For example, details about conversations between the complainant and the alleged offender, and other ways the complainant may have expressed that she did not consent (e.g., that she was distressed or trying to physically resist him) are powerful evidential details.

The first of three main ways to ensure the complainant provides the most complete and accurate account is to create a social and cognitive environment that is conducive to the complainant recalling and reporting what happened. One vital social factor is to ensure police attitudes encourage the complainant to stay in the criminal justice process when she initially reports to police, rather than police 'filtering out' the complaint before a formal interview (Kelly, Lovett, \& Regan, 2005). There is already a wide body of literature that examines the problems with disbelief about rape allegations and potential ways to improve police attitudes (Horney \& Spohn, 1996; Jordan, 2001; Kelly et al., 2005). This response may include providing medical care and encouraging the complainant to participate in an interview and thereby formally enter into the criminal justice process. During the interview process, this includes establishing rapport with the complainant to create an environment that they feel at ease, listened to and not judged (Fisher \& Geiselman, 1992; Milne \& Bull, 1999). Together these factors may also make the complainant feel more comfortable and motivated to disclose highly personal but relevant information such as the precise nature of the sexual acts (Kebbell \& Westera, 2011). Indeed, whilst specific aspects of a sex offence may be embarrassing and distressing (for both the 
complainant and the interviewing officer) this is exactly the information that is likely to be convincing to decision-makers and therefore interviewers should not shy away from eliciting this information. Some research into jury decision-making indicates that 'gruesome' violent evidence increases the likelihood juries will convict (Bright \& Goodman-Delahunty, 2006, 2011). It is possible this is also the case with gruesome sexual evidence. Despite these and other potential benefits to the investigation of making the complainant feel at ease, complainant's often report feeling judged, especially when the alleged offender is known to them (Jordan, 2001; McMillan $\&$ Thomas, 2009; Patterson, 2011). Not surprisingly, from interviews with 20 adult complainants of sexual assault, Patterson (2011) found that when a complainant felt judged by the interviewing officer she was less likely to provide detailed information about the alleged offence. This is consistent with a great deal of research that suggests that the community is more likely to help the police, for example by reporting crime and providing statements if they believe they will be treated fairly and with respect (Tyler, 2001; 2003).

In addition to social factors, cognitive factors will influence what a complainant reports. Offences may involve the use of alcohol or drugs and happen late at night. Arranging the interview for a time when the complainant is not tired or under the influence of alcohol or drugs is likely to improve her ability to concentrate and recall information from memory. A relaxed environment that is free from interruptions will also help the complainant to concentrate to the level required to recall detailed information (Fisher \& Geiselman, 1992). As well as providing a quiet and distraction-free interview room, this involves the interviewer allowing the witness to do most of the talking and not interrupt (see Fisher \& Geiselman, 1992; Powell et al., 2005). Although there have been improvements in recent years, many police stations do not have 
private and comfortable rooms for interviewing complainant or other types of witnesses and so interviews are conducted in a wholly inappropriate environment (Penney, 2007; Schollum, 2006).

Another important cognitive factor is to use questioning methods that encourage a narrative account from the complainant (Powell, Fisher, \& Wright, 2005). Research-driven recommended practice is to avoid leading or suggestive questions that imply the desired answer and can lead to memory distortions (Clifford \& Scott, 1978; Fisher \& Geiselman, 1992; Loftus \& Palmer, 1974; Milne \& Bull, 1999). Open questions or invitations that encourage unrestricted narrative responses are considered most desirable (Fisher \& Geiselman, 1992; Milne \& Bull, 1999; Powell et al., 2005). These types of questions allow a witness to control the flow of information and have been shown to generate more detailed, comprehensive, and accurate reporting (e.g., Fisher \& Geiselman, 1992; Hutcheson, Baxter, Telfer, \& Warden, 1995; Lipton, 1977; Powell et al., 2005). Open questions also enable the complainant to disclose potentially vital information that the interviewer may not have otherwise requested because they were not directly related to the reported crime. For example, details about the alleged offender intimidating the complainant prior to the reported event or behaviors that suggest the offender was grooming the complainant (Kebbell \& Westera, 2011; Westera, Kebbell, \& Milne, 2013a). Rather than free narrative responses, police interviews are often dominated by interruptions and closed questions that require a short response (Clifford \& George, 1996; Fisher, Geiselman, \& Raymond, 1987; Snook, Luther, Quinlan, \& Milne, 2012). Closed questions can be useful for clarifying aspects of the account or exploring ambiguous responses, but are unlikely to provide such rich information and may result in decreased accuracy due to social compliance (Hutcheson, Baxter, Telfer, \& Warden, 1995; Lipton, 1977). 
Using the cognitive interview (CI) is another way to improve the amount of information a complainant provides. This empirically validated method uses a number of memory aides, or mnemonics, that can increase the completeness of information remembered by an eyewitness (Fisher \& Geiselman, 1992; Geiselman et al., 1984; Fisher, Milne \& Bull, 2011). For example, a meta-analysis of the CI showed elicited an average of $41 \%$ more correct details when compared to control interviews without compromising overall accuracy rates (Köhnken, Milne, Memon, \& Bull, 1999; see Memon, Meissner, \& Fraser, 2010 for a recent meta-analysis). The mnemonics used are derived from encoding specificity theory that proposes memory recall is aided by an increased overlap between encoding and recall conditions (Fisher \& Geiselman, 1992; Geiselman, Fisher, MacKinnon, \& Holland, 1986; Tulving, 1972). For example, the mental reinstatement of context mnemonic involves the interviewer asking the witness to recreate the context of the crime; to where they were and how they were feeling at the time before giving an account of what happened.

In addition to the benefits of an overall increase in recall, some CI mnemonics may be particularly useful in rape cases, such as reporting from different sensory modalities. Most witness will primarily report what they saw, so asking them to report everything that they heard, felt, tasted and smelt may produce additional highly relevant information (Fisher \& Geiselman, 1992). In rape cases this may include specific details that go to the heart of whether sex was consensual. For instance if the alleged offender knew the sexual act was not consensual because the complainant explicitly said no or it was obvious because she was crying and distressed. The CI has also been shown to produce additional information about thoughts and emotions when compared to a control interview (McCabe, Krauss, \& Lieberman, 2010). This type of information may be vital for establishing issues around consent. For example, if the complainant 
froze due to fear it is important that decision-makers (e.g., prosecutors, jurors, judges) understand why she did not respond according to their stereotypes of how a victim should, a point we will explore further later.

Whilst the interview methods described can enhance reporting, research indicates that officers often have difficulty in applying the CI and using open questions (Clarke \& Milne, 2001; Clifford \& George, 1996; Griffiths, Milne, \& Cherryman, 2011). Part of the difficulty is that traditional police training regimes do not contain many of the key elements required for learning skills (Ericsson, Krampe, \& Tesch-Römer, 1993; Powell et al., 2005). In contrast to the short intensive training sessions common in policing organizations (Schollum, 2006; Shepherd and Milne, 2006), developing interviewing skills ideally requires training over multiple sessions, expert instruction and feedback, exemplars of good practice and motivated participants (Powell et al., 2005). In England and Wales, Clarke and Milne (2001) suggested training a small number of specialists could make this intensive training financially feasible for police. Despite this suggestion, New Zealand was the only country we could find that had published evidence of a police service adopting an ongoing development program with interviewers of adult complainants in a way that resembles evidence-based practice (New Zealand Police, 2012; this program has not been evaluated). Specialization may also assist with ensuring that police select interviewers who are genuinely motivated to improve their skills and have the resilience to deal with traumatized complainants.

In sum, the literature on interviewing complainants indicates a conducive interview environment, and using well-validated methodologies of questioning and interviewing, can dramatically improve the quality of information elicited from a complainant. Later we return to the issue of how all this extra information can be captured and used in the criminal justice 
process. Using the methods outlined to obtain information from the complainant should also enable investigators to improve their planning for the other main aspect of the investigation, the suspect interview.

\section{THE SUSPECT INTERVIEW}

How a suspect is interviewed is a system variable that is just as important as the how the complainant is interviewed. If a guilty suspect confesses then a conviction is almost inevitable, indeed the suspect will usually plead guilty prior to trial sparing the complainant the need to provide evidence in court (Gudjonsson, 2003). Of course being suspected of a sex crime is unpleasant, whether one is guilty or innocent, and particular care must be exercised to ensure the suspect's rights are taken into account. Fortunately, an increasingly sophisticated literature indicates there is much that can be done to ensure that suspects are both treated fairly and that the likelihood of eliciting an accurate account is enhanced.

Most notably, the literature indicates that the evidence against a suspect is highly influential on suspects' decisions to confess or deny. For example, Gudjonsson and Petursson (1991) surveyed 74 Icelandic prisoners concerning their reasons for confessing. Offenders were required to respond to questions using a Likert scale ranging from "not at all" (1 or 2) to "very much so" (6 or 7). The majority (55\%) of offenders gave scores of 6 or 7 to the question, "Did you think the police would eventually prove you did it? This was the most frequently given reason for confessing. Similarly, Moston, Stephenson, and Williamson (1992) investigated confessions for 1,067 suspects in the United Kingdom who had been interviewed by detectives for a range of crimes. The results showed that when the evidence was rated weak by researchers confessions occurred in less than $10 \%$ of cases. However, when evidence was rated as strong by the researchers, confessions occurred in $67 \%$ of cases. 
Specifically related to sex offenders, Kebbell, Alison, Hurren and Mazerolle (2010) surveyed 43 convicted Australian sex offenders concerning how they were interviewed and looked at how this related to their decisions to confess or deny. Evidence presenting strategies, both influenced offenders' decisions to confess to their own crimes and were suggested by respondents as being strategies that investigating officers should use to increase the likelihood of a suspect responding honestly. The implication of this is that officers should ensure they have the most evidence possible and the previous section concerning the complainant gives some guidance as to how this can be achieved. Indeed, providing the enhanced account to the suspect and/or his lawyer has the potential to demonstrate the strength of the evidence, if it is strong, and may facilitate suspects' truth telling.

Guilt may also effect decisions to confess. The previously mentioned research by Gudjonsson and Petursson (1991) indicated that 40\% of respondents gave a "very much so" rating to the question "Did you confess because you felt guilty about the offence". However in cases of sexual offending whilst guilt may drive a desire to confess, shame and fear of exposure may also drive a desire to deny the offence and hide from the associated stigma. Read, Powell, Kebbell and Milne (2009) therefore recommend adopting a non-judgmental approach that indicates to the suspect that his account will be heard, understood, and not judged. Convicted sex offenders strongly endorse interviewing strategies that they believe to be fair and not aggressive (Holmberg \& Christianson, 2002; Kebbell et al., 2010). This is in contrast with confession-based approaches prevalent in many countries that start from the assumption that the suspect is guilty and even sometimes actively discourage the suspect from giving their version of events (e.g., Inbau, Reid, \& Buckley, 1986). 
Adopting a free narrative approach, as pointed out by Read et al. (2009), is another method that may encourage the suspect to give a detailed and accurate account. Thus, asking the suspect (without assuming any wrong-doing) to give their version of the events or to explain the nature of their relationship with the alleged victim. This recommendation is consistent with a non-leading open-ended approach, which is the benchmark of best practice in prominent investigative interviewing protocols (e.g., Milne \& Bull, 1999). It is also consistent with the approach adopted by many clinicians to encourage disclosure of sensitive information in therapeutic settings (Royal College of Psychiatrists, 2004).

The value of using broad invitations when initially raising the topic of concern is threefold. First, open-ended invitations are perceived as non-threatening and less interrogative compared to a series of specific questions (i.e., those that dictate what specific information is required and offer the interviewee little time to collect his or her thoughts). This is because openended questions portray a relationship where interviewee's perspectives are valued and heard and because open-ended questions allow truly guilty suspects to portray themselves in a positive light, thus lowering their defenses. Second, open-ended questions minimize the risk that interviewers will raise specific case-related information (when discussing the allegation) in an attempt to confirm their preconceptions or prior knowledge (Meissner \& Kassin, 2004; Nickerson, 1998; Wason, 1960). Third, this allows the suspect to put their own "gloss" on their confession if they confess. For example, child sex offenders may wish to emphasize their personal bonds and relationships (Benneworth, 2007) whilst rapists may focus on criticizing the alleged victim's character and credibility. Both may wish to emphasize reasons why they are not fully culpable, for instance, that they are stressed or were under the influence of alcohol. 
Video technology now means that other decision makers in the justice system can also benefit from the higher quality of information generated from interviews with complainants and suspects. Instead, in many countries the norm is still to record the interview using the traditional method where the interviewer prepares a written statement that is later endorsed by the complainant or suspect as a record of interview (Heaton-Armstrong \& Wolchover, 1992). Barristers (e.g., Heaton-Armstrong \& Wolchover, 1992), linguists (e.g., Rock, 2001), psychologists and police officers (e.g., Milne \& Shaw, 1999; Shepherd, 1999; Westera, Kebbell, \& Milne, 2011) have all expressed concerns about this written statement process.

In suspect interviews, a move towards video or audio recording has been driven by a desire to make the interview process more transparent and open to scrutiny in an attempt to reduce unethical behavior by police and miscarriages of justice (Baldwin, 1993; Geller, 1993; Kassin et al., 2007). Since the early 1990's many, but not all, police services have responded by introducing mandatory video or at least audio recording of suspect interviews (Baldwin, 1993; Geller, 1993; Schollum, 2005) ${ }^{3}$. Concerns about the reliability of child witnesses have led to the mandatory recording of these interviews around the same time period in many countries (Advisory Group on Video Recorded Evidence, 1989; Davies, Wilson, Mitchell, \& Milsom, 1995; Goodman et al., 1998). Unfortunately the recording of adult witness interviews has been slower to change, and recording the interview on written statement is still commonplace (Schollum, 2005). Adult witness memory is fallible too. The cognitive and linguistic demands of the statement taking process on the interviewer, means the resultant statement is never the 'verbatim record' it is purported to be. Interviewers are unlikely to have the cognitive ability to remember and then record all that was said. For example, Köhnken, Thurer, and Zoberbier (1994) found 31 statements written by the interviewer immediately after the interview contained only 
about two thirds of the information reported by the witness. Furthermore, in an attempt to capture everything that is said, the interviewers report adopt interviewing methods that reduce the quality of information elicited such as interrupting the interviewee, and using repetitive and leading questioning (Westera, Kebbell \& Milne, 2011). The reconstructive nature of memory retrieval also means that when processing the information the interviewer may unconsciously use heuristics to fill in the gaps in his or her memory and misreport what was said (Bower, Black, \& Turner, 1979). Confirmation bias means the interviewer is more likely to remember information that supports their preconceptions of what happened, and disregard information that does not (Nickerson, 1998). For example, Rock (2001) found that when the audio recording of an interview was compared to the written statement resulting from it, contradictory information and the degree of the witness's uncertainty about central facts were often missing.

With video technology now readily available, video recording all interviews is a system variable that can be easily addressed and is likely to substantially improve the quality of evidence available. Vitally, capturing these accounts on video enables other decision makers in the justice system to access a far higher quality of information than was previously possible. Next, we explore how the justice system can make the most of this possibility.

\section{INVESTIGATION AND DECISIONS TO CHARGE}

In the five countries examined in Daly and Bouhours (2010) review of attrition studies ${ }^{4}$, on average only $30 \%$ of all cases reported to police resulting in a decision to prosecute. Higher quality accounts from the complainant and alleged offender is likely to improve these prospects. More detail about consent and what happened may also improve the evidential sufficiency of the case. Additional information may result in more investigative leads, which could increase the likelihood of corroboration with other evidence. For example, when there are multiple victims, 
more information about the alleged offender's modus operandi may corroborate their accounts and could later be used as similar fact evidence.

The additional details from the complainant may also improve her believability and with it the prospect that the case results in prosecution. A "culture of suspicion" is one reason given for the low rate of prosecutions by police (p.51, Kelly et al., 2005). In other words, the complainant is not believed due to tendency to overestimate the number of false complainants. Specifically, cases that depart from the common stereotype of 'real rape', when the offender is a stranger who physically overpowers a resisting complainant in a public place, are less likely to result in prosecution (Daly \& Bouhours, 2010; Estrich, 1987). Research suggests that when these stereotypes are not met, the complainant may be seen as behaving counter-intuitively or unreasonably and hence blameworthy (Horney \& Spohn, 1996; Jordan, 2001). This is particularly concerning because rape most commonly departs from this stereotype. For example, U.S. National Crime Victimization Survey data from 2005 to 2010 suggests $78 \%$ of victims knew the offender and 55\% of offences happened at or near the victim's home (Planty et al., 2013). It is important to note however that lawyers and members of the public have also been shown to hold these and other rape myths (Kerstetter, 1990; Schuller, McKimmie, Masser, \& Klippenstine, 2010; Temkin \& Krahé, 2008). Police may therefore choose not to prosecute if they anticipate there is no 'reasonable prospect of conviction' due to the biases jurors hold.

The police gathering more complete information from the complainant about her thoughts and emotions may help to overcome the negative effects of these 'rape myths' (Ellison, 2007; Kebbell \& Westera, 2011). This is because this information may make the complainant's behavior more understandable to outside observers. For example, the complainant explaining she did not physically resist the alleged offender because she was terrified and froze or that she was 
concerned that resistance would cause the level of violence to escalate. Not only may officers find the account more believable, but it may also bolster their perceptions about how believable the account would be to a jury and hence increase the likelihood they charge the alleged offender. Access to a video record means that decision-making by an investigator is open to scrutiny. An officer who holds strong rape myths and disbelieved the complainant may previously have 'shut down' the case after the complainant interview and recorded 'no complaint' or 'insufficient evidence'. The ability to review the interview may reduce the likelihood this will happen and can allow for effective case review and monitoring officer behavior.

\section{PRE-TRIAL DECISION-MAKING}

If the case results in a prosecution, a more complete and detailed record of interview is also likely to benefit pre-trial decision making for both the prosecution and defense. Lawyers report that video record enables them to improve case preparation because they can see first-hand what the complainant said and how they said it (Westera, Kebbell \& Milne, 2013b). For example, Sanders, Creaton, Bird and Weber (1997) found that many witnesses with intellectual disabilities appeared far more competent in their written statements than in fact they actually were. Reviewing the interview may also help to inform decisions to plea based on how credible a complainant or alleged offender is likely to appear to a jury. In addition, lawyers can scrutinize how the information was elicited to determine if this may have affected the reliability of that information (Heaton-Armstrong \& Wolchover, 1992; Powell et al., 2005; Westera, Kebbell \& Milne, 2013b). For example, information resulting from leading questions (e.g., 'did he put his fingers inside you that time?') may be considered less reliable than that gained from open questions (e.g., 'tell me what happened?'). 
The inclusion of additional information that may have previously been filtered out during the statement taking process makes the process fairer and will also likely improve case preparation for both the prosecution and the defense. In the example we used earlier concerning a complainant reporting that she froze during the sexual assault because she was terrified, a prosecutor may decide to call expert evidence that this is a common response to being raped (Ellison, 2007). Or where the information may have a negative impact on juror judgments about credibility (e.g., that the complainant used recreational drugs on the night of the alleged offence), it may be more effective for a prosecutor to introduce this information in advance rather than waiting for defense to do so in a more damaging way during cross-examination (Dolnik, Case, \& Williams, 2003; Evans, 1995). A better understanding of the case may result in earlier guilty pleas or decisions to discontinue the prosecution in cases. For the defense, when the prosecution case is strong, they may have a better basis from which to persuade the alleged offender to plead guilty. It may also reduce the likelihood a defendant will hope that the complainant will not turn up to give evidence or may be persuaded with intimidation to change their evidence.

For the benefits of improved accounts from the complainant and suspect to be realized lawyers need to review the interviews before trial, which will take longer compared to reviewing a written statement (Westera, Kebbell, \& Milne, 2013b). Studies suggest that this seldom happens and instead lawyers tend to rely on the, often unreliable and always incomplete, police statement or summary of interview (Baldwin \& Bedward, 1991; HMCPSI \& HMIC, 2007). Reviewing the interview is an opportunity to increase early resolutions and improve case outcomes, and is likely to save time in the long run. Next, we examine improvements that can be made to the criminal trial. 
The most powerful evidence in a rape trial is usually the account of the complainant. This is because in an adversarial criminal trial ${ }^{5}$, the onus is on the prosecution to present the jury or judge with evidence that establishes the guilt of the accused beyond a reasonable doubt. The complainant is usually the main prosecution witness and, traditionally, gives their account of what happened in the courtroom in response to questions from the prosecutor (known as direct evidence). Defense counsel then cross-examines the complainant in an attempt to discredit her testimony. One system variable, that may dramatically improve the quality of complainant evidence, is to use her video recorded police interview in the place of live courtroom direct evidence.

There are three main reasons why the video may provide more complete and reliable information to a jury or judge. First, it takes months and often a year or years between the initial reporting of the alleged offending and the trial (e.g., Westera, Kebbell, \& Milne, 2013a). This time delay is likely to lead to memory decay that reduces the completeness of the information (Ebbinghaus, 1913; Read \& Connolly, 2007; Rubin \& Wenzel, 1996); and provides an opportunity for memory distortions that may reduce information accuracy to occur (French, Garry, \& Kazuo, 2008; Gabbert, Memon, \& Allen, 2003; Loftus \& Palmer, 1974; Tuckey \& Brewer, 2003). Secondly, advocacy guidance recommends that prosecutors use questions that encourage short answers and control the witness. Studies of prosecutor questioning suggest they do predominantly use closed questions and, as previously discussed, this is likely to result in less detail than open questions that police are recommended to use (Kebbell, Deprez \& Wagstaff, 2002; Westera, Kebbell, \& Milne, 2013b; Zajac \& Cannan, 2009). Thirdly, the environment of the courtroom is likely to be detrimental to memory recall and reporting due to the stress of giving evidence (see Deffenbacher, Bornstein, Penrod, \& McGorty, 2004; Yerkes \& Dodson, 
1908). The formal setting is also likely to discourage the disclosure of highly personal details, which are often the highly relevant evidence such as the sexual acts that occurred (Konradi, 1999).

To see what differences video-evidence could make, Westera, Kebbell and Milne (2013a) compared the content of the complainant's video recorded police interview and their direct evidence in ten actual rape cases in New Zealand. The transcripts of the police video interview and live direct evidence from ten rape cases in New Zealand were coded for details that went towards establishing consent (e.g., 'I told him I didn't want him near me') and what happened during the commission of the alleged offence (e.g., from 'he pushed me onto the bed' until 'he rolled over and fell asleep'). The comparison found details in interview about these highly relevant matters were significantly more likely to be missing from, than included in, live direct evidence. Further, details about cognitions suffered the greatest loss and were virtually nonexistent in live evidence. As discussed these types of details may be especially important in rape cases because they may provide a plausible explanation that helps to counter rape myths. These findings suggest video-evidence could substantially increase the amount of evidence available to jurors or judges in rape cases.

Despite the potential benefits of video-evidence, legislation enabling this method is only available in some countries ${ }^{6}$ (Australian Law Reform Commission, 2010; Criminal Justice System, 2007; Mahoney et al., 2007), and in those countries, legal professionals tend to continue to rely on live evidence processes (Burton, Evans \& Sanders, 2006; Kingi \& Jordan, 2009; Stern, 2010). Part of this may be due to a traditional approach to courtroom practices, which assume 'an adult is perfectly capable of giving evidence' (Stern, 2010; Westera et al., 2013b). Over 40 years of memory research suggests this not the case ( $\operatorname{Read} \&$ Connolly, 2007). A reluctance to use 
video-evidence has recently led to legal reforms in England and Wales, that mean the prosecution must apply for alternative ways of evidence (Home Office, 2011; McDonald and Tinsely; 2011).

More research is required to examine exactly how video-evidence influences perceptions of adult complainant testimony. Some legal professionals are concerned that the video interview is less persuasive as evidence due to the video medium and narrative format of the interviews (Westera, Kebbell \& Milne, 2013b). Video-recorded evidence may however also capture other features that make the complainant more persuasive, but are diminished in live evidence due to both the length of time passed and courtroom environment. For example, both police and prosecutors perceive that the complainant is often more emotional at the time of interview than at trial and that this adds to complainant credibility (Westera, et al., 2011, 2013b). These perceptions are supported by studies that found jurors rate rape complainants as less credible if they do not display emotion (Dahl et al., 2007; Rose, Nadler, \& Clark, 2006; Wessel, Drevland, Eilersten, \& Magnussen, 2006). Whatever the case, video-evidence is likely to provide jurors with a more complete and fairer account of events.

A video recorded account from the complainant may also remedy two system problems, created through traditional processes, used to discredit the complainant during crossexamination. First, when police produce a written statement, a complainant may be crossexamined on the contradictions or omissions between her live evidence and the statement. This is problematic because some of these inconsistencies are likely generated from the unreliable statement taking process (Heaton-Armstrong \& Wolchover, 1992). Secondly, when live evidence is given (regardless of how the police interview is recorded), a witness may be cross-examined on discrepancies between the interview and live evidence. These discrepancies may have 
occurred naturally due to memory decay (see Read \& Connelly, 2007) or the effect of repeated recall attempts (see Brewer et al., 1999; Fisher, Brewer \& Mitchell, 2009). Of particular concern, is that cross-examination is used not just to suggest the witness is wrong about the discrepant item in question, but that their whole testimony is unreliable or dishonest (Evans, 1995). As jurors use consistency as a strong gauge for credibility the process problems just described may undiagnostically diminish the credibility of the complainant's entire testimony (Berman, Narby, \& Cutler, 1995; Brewer et al., 1999; Fisher et al., 2009; Leippe \& Romanczyk, 1989; Oeberst, 2012).

To recap, gathering more complete evidence from the complainant and suspect can assist decision makers in the investigation and prosecution process, but processes to ensure this happens are not fully utilized by the justice system. Now we turn our attention to system variables that may serve to improve broader criminal justice system responses to rape and rapists. The quality of evidence will directly feed into justice outcomes around, sentencing, alternative resolution, and intelligence.

\section{SENTENCING}

With sentencing, a more thorough approach to interviewing the complainant and the suspect that gathers more detail about the nature of the offending may help to identify both mitigating and aggravating features of the crime as they were at the time rather than relying on a self-serving and limited reinterpretation of events some time later. A narrative approach to interviewing may also generate information about the offender's lifestyle, mental health, alcohol and drug use. This type of information may help determine what sentencing principles apply: rehabilitation, incapacitation, punishment or deterrence (Findlay, Odgers, \& Yeo, 2009). For instance, a different response may be desirable when there is evidence of heterogeneous and 
prolific criminality compared to sexual fetishism or a single isolated sexual abuse incident. Sadistic behavior may indicate that a perpetrator needs to be incapacitated (Mann, Hanson, \& Thornton, 2010). Having additional information that may help to negate rape myths may also reduce complainant blame and sentencing decisions are informed by a fairer representation of the harm done. Indeed, appropriate sentencing may allow the offender to have access to treatment programs that not only reduce their risk but also may give them the necessary skills to live more happy productive lives (Ward \& Brown, 2004). Additional problematic behaviors may also be identified, for instance, substance use at the time of the offence may indicate a general need for an alcohol or drug dependency intervention.

When rehabilitation is the objective, with the complainant's consent, her interview record may be used as part of offender treatment. Viewing the complainant's interview may help the offender to understand the impact of their actions. It also may counter any justification and minimization of what happened, which is an important step in therapeutic interventions. Further, having a full account may also help to identify, diagnose and treat any mental health issues such as alcohol and drug dependence, sexual deviance, or mental disorder and prevent the offender from manipulating the treatment providers about what happened. There is also a growing desire to increase options for addressing sexual offending that are outside of a traditional justice sector responses, such as restorative justice (Daly \& Bouhours, 2010; MacDonald \& Tinsely, 2011). In these cases, where the complainant has initially reported the matter to police, the interview record may form a useful starting point to enable the alleged offender to understand the consequences of their actions.

INTELLIGENCE 
We started this paper by stating the low conviction rate for rape and have suggested a number of strategies that can be implemented to enhance how the police deal with rape. However, even with these strategies many guilty rapists will not be convicted - what should be done with these people? No criminal justice sanction can be applied without them being convicted of an offence. However, once the police are aware of serious allegations against an individual they should consider what risk that individual might pose in the future to the complainant and the community at large. Whilst the previous sections have a substantial research basis what we are suggesting now concerns police intelligence and is more speculative but has the potential to reduce sex offending and offending more generally.

Policing has traditionally been reactive: a crime is reported and then it is investigated. More recently some police services have moved to an intelligence-led approach whereby police attempt to prevent crime before it occurs or target emerging crime-problems and prolific offenders (Ratcliffe, 2003). This is relevant to rape investigations as it is clear that many rape suspects have committed many other offences in the past and will commit many offences in the future. For instance, in a sample of 14,804 men in England and Wales convicted of contact sex offences against an adult, overall $84 \%$ had previous non-sexual convictions with $76 \%$ having previous convictions for non-sexual violence and $71 \%$ for non-violent offences (Howard, Barnett, \& Mann, 2013). Of these offenders $47 \%$ were subsequently convicted of a non-sexual offence after release whilst only $2 \%$ were convicted of a contact offence against an adult (with all the previously mentioned difficulties around conviction meaning we must be cautious about how valid a measure this is of actual sex offending). What this means is that many offenders are not only rapists, but are committing offences across a range of domains. Indeed, high-risk sex offenders are more likely to commit a non-sexual offence than a sex offence as their next offence 
(see for example, Smallbone \& Rallings, 2013). This suggests that high risk sex offenders may be at high risk of offending generally rather than just of sex offending and, given the difficulty in prosecuting sex crime, prosecuting them for other offences may be an alternative strategy.

One positive side effect of effective interviewing of complainants is that much more collateral information about suspects is available to investigators. For example, the authors recently reviewed ten interviews with rape complainants for a study (Westera et al., 2013a). In these interviews most of the complainants already knew the suspect and were familiar with his background. In the interviews complainants gave a great deal of information about the suspects committing other offences. For example, in one interview the complainant identified her alleged rapist as repeatedly drink-driving, in another the complainant linked the suspect with a murder and named an accomplice, and in another the complainant said the suspect had an illegal firearm and was dealing in drugs. Clearly, this is intelligence information that can be used in police operations and can be combined with what the police already know about the suspect from his previous convictions and from other intelligence. While it may mean that offender is not held accountable for his rape, he can be held accountable for other antisocial behavior.

Given the difficulties in successfully convicting rapists it is important that intelligence is kept on those who have been suspected of rape. Previously we have mentioned the skepticism that some police may have over some allegations. This skepticism will be reduced if multiple allegations are made against the same perpetrator by a number of women who do not know each other. An example of this is the case of serial rapist John Worboys, the London "Black Cab Rapist". Worboys could possibly be the England's most prolific rapist and is thought to have raped more than a 100 women. The sheer number of victims makes the case too complex to provide all the details here (for the inquiry see Independent Police Complaints Commission, 
2010) and there are multiple reasons why Worboys was free to carry on raping for so long. However, three main factors stand out. First, many aspects of the investigation were of poor quality especially the interviewing of complainants and the suspect. Second, some victims were not believed and so the allegations were not pursued. Third, there was no intelligence collation to show that there were a number of allegations against a taxi driver with the same modus operandi and a similar description. Of course these errors compounded one-another. However, if the intelligence had been available to investigating officers that linked the attacks it is likely they would have investigated more thoroughly, believed the complainants, and pursued the matter more tenaciously.

The implication of all this is that intelligence needs to be collated and used in rape cases. Indeed, by systematically using the information produced by rape investigations it might also be possible to generate intelligence around rape. A better understanding of a rapist's particular modus operandi may help police to develop targeted prevention measures (Smallbone \& Wortley, 2006). Similarly, allegations might be focused at particular times or places that may benefit from police attention. For example, offences may be particularly likely in an entertainment district offering cheap alcohol or at particular times where police presence may reduce victimization.

\section{CONCLUSION}

The hidden nature of sexual offending and persistence of complainant blaming attitudes makes achieving just outcomes an on-going challenge for the criminal justice system. For those involved in the process the stakes are high, whether ensuring the recovery of survivors, preventing wrongful convictions, or minimizing the risk re-offending. At a minimum, the criminal justice system must do all it can to ensure the information central to determining 
outcomes in these difficult to investigate cases is gathered in a fair and transparent way. Key decision makers, both within and beyond the criminal justice process, must have access to the most accurate and complete information possible. By applying the same standard of care expected of a crime scene examination to how information is gathered from the complainant and the alleged offender, investigators can improve the quality of information obtained and preserved. Methods for doing so are well documented, within control of the justice system and can be implemented now. Adopting these methods will not only improve outcomes within and outside of the justice process, but also the responsiveness of that process to those with the most at stake. Taken together these approaches can improve rape investigation and prosecution dramatically. 


\section{REFERENCES}

Advisory Group on Video Recorded Evidence. (1989). Report of the Advisory Group on Video Recorded Evidence. London: Home Office.

Australian Law Reform Commission. (2010). Family Violence - A National Legal Response. Retrieved on 30 March 2012 from http://www.alrc.gov.au/26.\%20Reporting,20\%Prosecutionand\%20Pretrialprocesses

Baldwin, J. (1993). Police interviewing techniques: Establishing truth or proof? British Journal of Criminology, 33, 325-351.

Baldwin, J., \& Bedward, J. (1991). Summarizing tape recordings of police interviews. Criminal Law Review, 671-679.

Benneworth, K. (2007). Repertoires of pedophilia: Conflicting descriptions of adult-child sexual relationships in the investigative interview. International Journal of Speech Language and the Law, 13, 189-211.

Berman, G. L., Narby, D. J., \& Cutler, B. L. (1995). Effects of inconsistent eyewitness statements on mock jurors' evaluations of eyewitness, perceptions of defendant culpability and verdicts. Law and Human Behavior, 19, 79-88.

Bower, G. H., Black, J. B., \& Turner, T. J. (1979). Scripts in memory for text. Cognitive Psychology, 11, 177-220.

Brewer, N., Potter, R., Fisher, R. P., Bond, N., \& Luszcz, M. A. (1999). Beliefs and data on the relationship between consistency and accuracy of eyewitness testimony. Applied Cognitive Psychology, 13, 297-313. 
Bright, D. A., \& Goodman-Delahunty, J. (2006). Gruesome evidence and emotion: Anger, blame, and jury decision-making. Law and Human Behavior, 30, 183-202.

Bright, D. A., \& Goodman-Delahunty, J. (2011). Mock juror decision making in a civil negligence trial: The impact of gruesome evidence, injury severity, and information processing route. Psychiatry, Psychology and Law, 18, 439-459.

Clarke, C., \& Milne, R. (2001). National evaluation of the PEACE investigative interviewing course. Police Research Award Scheme: Report No. PRAS/149. Portsmouth: University of Portsmouth.

Clifford, B. R., \& George, R. (1996). A field evaluation of training in three methods of witness/victim investigative interviewing. Psychology, Crime \& Law, 2, 231-248.

Criminal Justice System. (2007). Achieving best evidence in criminal proceedings: Guidance in interviewing victims and witnesses, and using special measures. London: Home Office.

Dahl, J., Enemo, I., Drevland, G. C. B., Wessel, E., Eilertsen, D. E., \& Magnussen, S. (2007). Displayed emotion and witness credibility: a comparison of judgments by individuals and mock juries. Applied Cognitive Psychology, 21, 1145-1155.

Daly, K., \& Bouhours, B. (2010). Rape and attrition in the legal process: A comparative analysis of five countries. Crime and Justice: An Annual Review of Research, 39, 565-650.

Davies, G., Wilson, C., Mitchell, R., \& Milsom, J. (1995). Videotaping children's evidence: An evaluation. London: Home Office.

Deffenbacher, K. A., Bornstein, B. H., Penrod, S. D., \& McGorty, E. K. (2004). A meta-analytic review of the effects of high stress on eyewitness memory. Law and Human Behavior, 28, $687-706$. 
Dolnik, L., Case, T. I., \& Williams, K. D. (2003). Stealing thunder as a courtroom tactic revisited: Processes and boundaries. Law and Human Behavior, 27, 267-287.

Ebbinghaus, H. (1913). Memory: A contribution to experimental psychology. (H.A.Ruger \& C.E.Bussenius, Trans). New York: US Teachers College Press.

Edwards, J. (2003). Medical examinations of sexual assault victims: Forensic use and relevance. Judicial officers' bulletin, 15, 65-72.

Ellison, L. (2007). Promoting effective case-building in rape cases: a comparative perspective. Criminal Law Review, 691-708.

Ericsson, K. A., Krampe, R. T., \& Tesch-Römer, C. (1993). The role of deliberate practice in the acquisition of expert performance. Psychological Review, 100, 363-406.

Estrich, S. (1987). Real rape. Cambridge, Massachusetts: Harvard University Press.

Evans, K. (1995). Advocacy in court: A beginner's guide (2nd ed.). London: Blackstone.

Findlay, M., Odgers, S., \& Yeo, S. (2009). Australian Criminal Justice. Melbourne: Oxford University Press.

Fisher, R. P., Brewer, N., \& Mitchell, G. (2009). The relation between consistency and accuracy of eyewitness testimony: Legal versus cognitive explanations. In T.Williamson, R.Bull \& T.Valentine (Eds.), Handbook of Psychology of Investigative Interviewing: Current Developments and Future Directions (pp. 121-136). Chichester: John Wiley \& Sons.

Fisher, R. P., \& Geiselman, R. E. (1992). Memory enhancing techniques for investigative interviewing: The cognitive interview. Springfield, IL: Thomas.

Fisher, R. P., Geiselman, R. E., \& Raymond, D. S. (1987). Critical analysis of police interview techniques. Journal of Police Science \& Administration, 15, 177-185. 
Fisher, R. P., Milne, R., \& Bull, R. (2011). Interviewing cooperative witnesses. Current Directions in Psychological Science, 20, 16-19.

French, L., Garry, M., \& Kazuo, M. (2008). You say tomato? Collaborative remembering leads to more false memories for intimate couples than for strangers. Memory, 16, 262-273.

Gabbert, F., Memon, A., \& Allen, K. (2003). Memory conformity: Disentangling the steps toward influence during a discussion. Applied Cognitive Psychology, 17, 533-543.

Geiselman, R. E., Fisher, R. P., Cohen, G., Holland, H., \& Surtes, L. (1986). Eyewitness responses to leading and misleading questions under the cognitive interview. Journal of Police Science \& Administration, 14, 31-39.

Geiselman, R. E., Fisher, R. P., Firstenberg, I., Hutton, L. A., Sullivan, S. J., Avetissian, I. V., \& Prosk, A. L. (1984). Enhancement of eyewitness memory: An empirical evaluation of the cognitive interview. Journal of Police Science \& Administration, 12, 74-80.

Geller, W. A. (1993). Police videotaping of suspect interrogations and confessions: A preliminary examination of issues and practices. Washington: National Institute of Justice.

Goodman, G. S., Tobey, A. E., Batterman-Faunce, J. M., Orcutt, H. K., Thomas, S., Shapiro, C., \& Sachsenmaier, T. (1998). Face-to-face confrontation: Effects of closed-circuit technology on children's testimony and jurors' decisions. Law and Human Behavior, 22, 165-203.

Griffiths, A., Milne, B., \& Cherryman, J. (2011). A question of control? The formulation of suspect and witness interview question strategies by advanced interviewers. International Journal of Police Science \& Management, 13, 255-267. 
Gudjonsson, G. H. (2003). The psychology of interrogations and confessions: A handbook. Chichester: Wiley.

Gudjonsson, G. H., \& Petursson, H. (1991). Custodial interrogation: Why do suspects confess and how does it relate to their crime, attitude and personality? Personality and Individual Differences, 12, 295-306.

Heaton-Armstrong, A., \& Wolchover, D. (1992). Recording witness statements. Criminal Law Review, 160-172.

Herman, J. L. (2005). Justice from the victim's perspective. Violence Against Women, 11, 571602.

HMCPSI, \& HMIC. (2007). Without consent: A report on the joint review of the investigation and prosecution of rape cases. London: HM Crown Prosecution Service Inspectorate \& HM Inspectorate of Constabulary.

Holmberg, U., \& Christianson, S. (2002). Murderers' and sexual offenders' experiences of police interviews and their inclination to admit or deny crimes. Behavioral Sciences and the Law, 20, 31-45.

Home Office. (2011). The Government Response to the Stern Review: An independent review into how rape complaints are handled by public authorities in England and Wales. London: Home Office.

Horney, J., \& Spohn, C. (1996). The influence of blame and believability factors on the processing of simple versus aggravated rape cases. Criminology, 34, 135-162.

Howard, P.D., Barnett, G. \& Mann, R.E. (2013). Specialization in and within sexual offending in England and Wales. Sexual Abuse: A Journal of Research and Treatment, Online first. 
Hutcheson, G. D., Baxter, J. S., Telfer, K., \& Warden, D. (1995). Child witness statement quality: Question type and errors of omission. Law and Human Behavior, 19, 631-648.

Inbau, F. E., Reid, J. E., \& Buckley, J. P. (1986). Criminal interrogation and confessions (3rd ed.). Baltimore: Williams \& Wilkins.

Independent Police Complaints Commission (2010). IPCC independent investigation into the Metropolitan Police Service's inquiry into allegations against John Worboys. London: Independent Police Complaints Commission.

Johnson, D., Peterson, J., Sommers, I., \& Baskin, D. (2012). Contrasting its theoretical potential with empirical realities use of forensic science in investigating crimes of sexual violence. Violence Against Women, 18, 193-222.

Jordan, J. (2001). Worlds apart? Women, rape and the police reporting process. British Journal of Criminology, 41, 679-706.

Kassin, S. M., Leo, R., Meissner, C. A., Richman, K., Colwell, L., Leach, A., \& La Fon, D. (2007). Police interviewing and interrogation: A self-report survey of police practices and beliefs. Law and Human Behavior, 31, 381-400.

Kebbell, M. R., Allison, L. J., Hurren, E. J., \& Mazerolle, P. (2010). How do sex offenders think police should interview to elicit confessions from sex offenders? Psychology, Crime \& Law, 16, 567-584.

Kebbell, M. R., Deprez, S., \& Wagstaff, G. F. (2003). The direct and cross-examination of complainants and defendants in rape trials: A quantitative analysis of question type. Psychology, Crime \& Law, 9, 49-59.

Kebbell, M. R., \& Westera, N. J. (2011). Promoting pre-recorded complainant evidence in rape trials: Psychological and practice perspectives. Criminal Law Journal, 35, 376-385. 
Kelly, L., Lovett, J., \& Regan, L. (2005). A gap or a chasm? Attrition in reported rape cases. Home Office Research Study 293. London: Home Office. Retrieved on 1 April 2009 from http://www.homeoffice.gov.uk/rds/index.htm

Kerstetter, W. A. (1990). Gateway to justice: Police and prosecutorial response to sexual assaults against women. Criminology, 81, 267-313.

Kingi, V., \& Jordan, J. (2009). Responding to sexual violence: Pathways to recovery. Wellington: Ministry of Women's Affairs.

Köhnken, G., Milne, R., Memon, A., \& Bull, R. (1999). The cognitive interview: a meta-analysis. Psychology, Crime \& Law, 5, 3-27.

Köhnken, G., Thurer, C., \& Zoberbier, D. (1994). The cognitive interview: are interviewers' memories enhanced, too? Applied Cognitive Psychology, 8, 13-24.

Konradi, A. (1999). "I don't have to be afraid of you": Rape survivors' emotion management in court. Symbolic Interaction, 22, 45-77.

Lees, S. (2002). Carnal knowledge: Rape on trial (2nd ed.). London: The Women's Press.

Leippe, M. R., \& Romanczyk, A. (1989). Reactions to child (versus adult) eyewitnesses: the influence of jurors' preconceptions and witness behavior. Law and Human Behavior, 13, $103-132$.

Lipton, J. P. (1977). On the psychology of eyewitness testimony. Journal of Applied Psychology, 62, 90-95.

Loftus, E. F., \& Palmer, J. C. (1974). Reconstruction of automobile destruction: an example of the interaction between language and memory. Journal of Verbal Learning and Verbal Behavior, 13, 585-589. 
McCabe, J. G., Krauss, D. A., \& Lieberman, J. D. (2010). Reality check: A comparison of college students and a community sample of mock jurors in a simulated sexual violent predator civil commitment. Behavioral Sciences and the Law, 28, 730-750.

McDonald, E., \& Tinsley, Y. (2011). From “Real rape” to real justice: Prosecuting rape in New Zealand. Victoria University Press: Wellington.

McMillan, L., \& Thomas, M. (2009). Police interviews of rape victims: Tensions and contradictions. In M. Horvath \& J. Brown (Eds.), Rape: Challenging contemporary thinking (pp. 255-280). Devon: Willan Publishing.

Mahoney, R., McDonald, E., Optican, S., \& Tinsley, Y. (2007). The Evidence Act 2006: Act and analysis. Wellington: Brookers.

Mann, R.E., Hanson, R.K., \& Thornton, D. (2010). Assessing Risk for Sexual Recidivism: Some Proposals on the Nature of Psychologically Meaningful Risk Factors. Sexual Abuse: A Journal of Research and Treatment, 22, 191-217.

Meissner, C. A., \& Kassin, S. M. (2002). "He's guilty!”: Investigator bias in judgments of truth and deception. Law and Human Behavior, 26, 469-480.

Memon, A., Meissner, C. A., \& Fraser, J. (2010). The cognitive interview: A meta-analytic review and study space analysis of the past 25 years. Psychology, Public Policy and Law, $16,340-372$.

Milne, R., \& Bull, R. (1999). Investigative interviewing: psychology and practice. Chichester: Wiley.

Milne, R., \& Shaw, G. (1999). Obtaining witness statements: The psychology, best practice and proposals for innovation. Medicine, Science and the Law, 39, 127-137. 
Moston, S., Stephenson, G. M., \& Williamson, T. (1992). The effects of case characteristics on suspect behaviour during police questioning. British Journal of Criminology, 32, 23-40.

New Zealand Police. (2012). Investigative interviewing accreditation policy. Wellington: New Zealand Police.

Nickerson, R. F. (1998). Confirmation bias: A ubiquitous phenomenon in many guises. Review of General Psychology, 2, 175-220.

Oeberst, A. (2011). If anything else come to mind... Better keep it to yourself? Delayed recall is discrediting-unjustifiably. Law and Human Behavior, 36, 266-274.

Patterson, D. (2011). The impact of detectives' manner of questioning on rape victims' disclosure. Violence Against Women, 17, 1349-1373.

Penney, J. (2007). Investigative interviewing: Equipment and rooms. Wellington: New Zealand Police.

Planty, M., Langton, L., Krebs, C., Berzofsky, M., \& Smiley-McDonald, H. (2013). Female victims of sexual violence, 1994-2010. Washington: U.S. Department of Justice.

Powell, M. B., Fisher, R. P., \& Wright, R. (2005). Investigative interviewing. In N. Brewer \& K. Williams (Eds.), Psychology and law: An empirical perspective (pp. 11-42). New York: Guilford.

Ratcliffe, J.H. (2003). Intelligence-led policing. Trends and Issues in Crime and Criminal Justice, 248, 248-260.

Read, J. D., \& Connolly, A. (2007). The effects of delay on long-term memory for witnessed events. In M. P. Toglia, Read, J. D., Ross, D. R., \& Lindsay, R. C. L. (Ed.), Handbook of eyewitness psychology: Volume I Memory for events (pp. 117-155). New York: Lawrence Erlbaum Associates. 
Read, J. M., Powell, M. B., Kebbell, M. R., \& Milne, R. (2009). Investigative interviewing of suspected sex offenders: A review of what constitutes best practice. International Journal of Police Science \& Management, 11, 442-459.

Rock, F. (2001). The genesis of a witness statement. Forensic Linguistics, 8, 44-72.

Rose, M. R., Nadler, J., \& Clark, J. (2006). Appropriately upset? Emotion norms and perceptions of crime victims. Law and Human Behavior, 30, 203-219.

Royal College of Psychiatrists (1995). Looking at the assessment of sex offenders (DVD). Gaskell: London.

Rubin, D. C., \& Wenzel, A. E. (1996). One hundred years of forgetting: A quantitative description of retention. Psychological Review, 103, 734-760.

Sanders, A., Creaton, J., Bird, S., \& Weber, L. (1996). Witnesses with learning disabilities. Retrieved on 13 February 2013 from http://www.homeoffice.gov.uk/rds/pdfs/r44.pdf

Schollum, M. (2005). Investigative interviewing: The literature. Wellington: New Zealand Police.

Schollum, M. (2006). Investigative interviewing: The current situation. Wellington: New Zealand Police.

Schuller, R. A., McKimmie, B. M., Masser, B. M., \& Klippenstine, M. A. (2010). Judgments of sexual assault: the impact of complainant emotional demeanor, gender, and victim stereotypes. New Criminal Law Review, 13, 759-780.

Shepherd, E. (1999). 'Non-barking dogs and other odd species': Identifying anomaly in witness testimony. Medicine, Science and the Law, 39, 138-145.

Shepherd, E., \& Milne, R. (2006). 'Have you told management about this?' Bringing witness interviewing into the twenty-first century. In A. Heaton-Armstrong, E. Shepherd, 
G.H.Gudjonsson, \& D.Wolchover (Ed.), Witness testimony: Psychological, investigative and evidential perspectives (pp. 131-152). Oxford: Oxford University Press.

Smallbone, S. \& Rallings, M. (2013). Short-Term Predictive Validity of the Static-99 and Static99-R for Indigenous and Nonindigenous Australian Sexual Offenders. Sex Abuse. 2013 Feb 6. [Epub ahead of print]

Snook, B., Luther, K., Quinlan, H., \& Milne, B. (2012). Let 'em talk! A field study of police questioning practices of suspects and accused persons. Criminal Justice and Behavior, $19,595-610$.

Stern, V. (2010). The Stern Review. London: Home Office.

Temkin, J., \& Krahé, B. (2008). Sexual assault and the justice gap: A question of attitude. Portland: Hart Publishing.

Tuckey, M. R., \& Brewer, N. (2003). The influence of schemas, stimulus ambiguity, and interview schedule on eyewitness memory over time. Journal of Experimental Psychology: Applied, 9, 101-118.

Tulving, E. (1972). Episodic and semantic memory. In E. Tulving \& W. Donaldson (Eds.), Organization of memory (pp. 382-403). Oxford: Academic Press.

Tyler, T.R. (2001). Public trust and confidence in legal authorities: What do majority and minority group members want from the law and legal institutions? Behavioral Sciences \& the Law, 19, 215-235.

Tyler, T.R. (2003). Procedural Justice, Legitimacy, and the Effective Rule of Law, Crime and Justice, 30, 283-357.

Ward, T. \& Brown, M. (2004). The good lives model and conceptual issues in offender rehabilitation. Psychology, Crime and Law, 10, 243-257. 
Ward, T., Polaschek, D.L.L. and Beech, A.R. (2006). Theories of sexual offending. John Wiley \& Sons: Hoboken, N. J.

Wason, P.C. (1960). On the failure to eliminate hypotheses in a conceptual task. Quarterly Journal of Experimental Psychology, 12, 129-137.

Wells, G. L. (1978). Applied eyewitness-testimony research: System variables and estimator variables. Journal of Personality and Social Psychology, 36, 1546-1557.

Wessel, E., Drevland, G. C. B., Eilersten, D. E., \& Magnussen, S. (2006). Credibility of the emotional witness: a study of ratings by court judges. Law and Human Behavior, 30, 221-230.

Westera, N., Kebbell, M. R., \& Milne, R. (2011). Interviewing rape complainants: Police officers' perceptions of interview format and quality of evidence. Applied Cognitive Psychology, 25, 917-926.

Westera, N., Kebbell, M., \& Milne, B. (2013a). Losing two thirds of the story: A comparison of the video recorded police interview and live evidence of rape complainants. Criminal Law Review, 4, 290-308.

Westera, N., Kebbell, M., \& Milne, B. (2013b). It is better, but does it look better? Prosecutor perceptions of using rape complainant investigative interviews as evidence Psychology, Crime \& Law, 19, 595-610.

Wortley, R., \& Smallbone, S. (2006). Situational prevention of child sexual abuse (Vol. 19). Monsey, NY: Criminal Justice Press.

Zajac, R., \& Cannan, P. (2009). Cross-examination of sexual assault complainants: A developmental comparison. Psychiatry, Psychology and Law, 16, 36-54. 
Yerkes, R. M., \& Dodson, J. D. (1908). The relation of strength of stimulus to rapidity of habitformation. Journal of Comparative Neurology \& Psychology, 18, 459-482. 


\section{NOTES}

${ }^{1}$ In this article we specifically examine alleged sex offences by males against adult female victims to reflect the gendered nature typical of this type of violence (see Estrich, 1987). We do not mean to undermine the traumatic effect of sexual violence when the victim is a male and many of the interventions described in this article will also likely apply to this group.

${ }^{2}$ In common law countries such as the United States, Canada, United Kingdom, Scotland, Australia, and New Zealand.

${ }^{3}$ England and Wales, Australia and New Zealand.

${ }^{4}$ The United States, Canada, England and Wales, Scotland, and Australia.

${ }^{5}$ In common law countries.

${ }^{6}$ We are only aware of this mode of evidence being available in England, Wales, Northern Ireland, Norway, New Zealand, and the Northern Territory of Australia. 